\title{
Performance of a snow blower prototype mounted on different vehicles type
}

\author{
Marco Manzone, ${ }^{1}$ Bruno Ruffinengo ${ }^{2}$ \\ ${ }^{1}$ Department of Agricultural, Forest and Food Sciences, University of Torino, Grugliasco (TO), Italy; \\ ${ }^{2}$ Designer and manufacturer of the prototype tested, Halifax, Nova Scotia, Canada
}

\begin{abstract}
All transportation sectors, in many countries of the world have shown problems related to the presence of snow on roads. The purpose of this work was to evaluate the performances of a snow blower prototype that can be attached in front of different commercial vehicle types (quad-bike, car, and small tractor) specifically developed for urban areas and private use. The prototype was tested using three different pavement types (bare soil, concrete, and asphalt) and with different snow layer thickness (50, $100,150,200,250$, and $300 \mathrm{~mm})$. The highest forward speed $(2.51$ $\mathrm{km} \mathrm{h}^{-1}$ ) was obtained using the car on asphalt pavement working with a snow layer thickness of $50 \mathrm{~mm}$. In contrast, the lowest forward speed $\left(0.28 \mathrm{~km} \mathrm{~h}^{-1}\right)$ was observed when the prototype was fixed to the quad-bike and it worked on concrete base with a snow depth of $300 \mathrm{~mm}$. The forward speed, and consequently also the productivity, varied only as a function of snow thickness. The prototype has demonstrated functional quality in all testing conditions leaving only a snow residue after its passage of about $0.18 \mathrm{dm}^{3}$ on 100 meter of road. The hourly fuel consumption varied between 6.56 and 6.68 litres highlighting an average specific fuel consumption of $319.5 \mathrm{~g} \mathrm{kWh}^{-1}$. The snow blower prototype, as it demonstrated good performance in all tested working conditions, seems to be a valid solution in snow-removal especially in private areas where the equipment versatility plays a fundamental rule.
\end{abstract}

\section{Introduction}

All transportation sectors, in many countries of the world have shown problems related to the presence of snow. In fact, driving

Correspondence: Marco Manzone, Department of Agricultural, Forest and Food Sciences, University of Torino, Largo Paolo Braccini, 2, 10095 Grugliasco (TO), Italy.

E-mail: marco.manzone@unito.it

Key words: Snow blower; vehicles type; performances; fuel consumption; working time.

Received for publication: 5 December 2018.

Accepted for publication: 20 February 2019.

CCopyright M. Manzone and B. Ruffinengo, 2019

Licensee PAGEPress, Italy

Journal of Agricultural Engineering 2019; L:929

doi:10.4081/jae.2019.929

This article is distributed under the terms of the Creative Commons Attribution Noncommercial License (by-nc 4.0) which permits any noncommercial use, distribution, and reproduction in any medium, provided the original author(s) and source are credited. in these conditions can become very dangerous due to significant reduction in pavement friction and increasing the risk of accidents (Nixon and Qiu, 2008). Some studies have addressed the issue that having roads and sidewalks covered with snow can cause problems also in economic terms linked mainly to higher average transit time (Ninon et al., 1996). In addition, some authors have underlined also the importance to consider the ice and snow presence during the road and highway construction (Sarsembayeva and Collins, 2017).

The snow density mainly depends on environmental and climatic conditions. Generally, it increase with the increase of the air humidity. Snow deposit can be affected also by air temperature: higher the air temperature, higher compacted is the snow (Wooseng et al., 2010). Nevertheless, the amount and the persistence of snow on roads depends also on soil type and from solar radiation on sunny days. Artificial layers (concrete, asphalt, ...) show a higher temperature because they are good absorbers of solar energy.

Due to safety and economic concerns, it is unquestionably necessary to maintain snow-free roads. Additionally, increased environmental impacts (e.g. carbon footprint) can be caused by slowing vehicles (Dominici et al., 2014). At present, the common solutions to guarantee safe road conditions during wintertime are vehicles equipped with snowplows, snow blowers, and salt spreaders or the use of snow melting materials (Laurinavicius et al., 2016). In the last years, many improvements were made on salts spreading vehicles in order to offer a good level of accuracy on salt spreading and a reduction of related costs (Defina et al., 2015). Some studies discussing snow-removing operations were focused also on dynamic vehicles routing problems and management (Hajibabai and Ouyang, 2016). Furthermore, there are also two works that consider vehicle routing, roadway types (i.e., single and multi-lane roads) and snow intensity rating. Perrier et al. (2007) proposed two solutions to optimise the routing of plowing vehicles in urban areas but his model did not consider the plowing pattern and varying pavement width of snow. Successively, these aspects were evaluated by Salazar-Aguilar et al. (2012) where they recommended that road sections with two or more lanes per direction shall be plowed simultaneously.

In contrast, there are few studies discussing the machines and implements performances during snow and ice removing or focused on the development of innovative technologies and prototypes specified applied to this purpose. In order to address this, a specific machine for ice removing set up by Doudkin et al. (2013) shall be cited in this section. This prototype, in fact, developed for ice breaking and chipping seem to be a valid solution not only in roads and highway, but also in sidewalks and other hard-access areas. Nevertheless, this innovative machine shows a low versatility because can work only on ice presence and its frame is designed only for a manual management. In order to improve the knowledge of the machines used in snow removal, the purpose of this study is the performances evaluation of a snow blower prototype that can be attached in front of different commercial vehicle 
types (quad-bike, car, and small tractor) specifically developed for urban areas and private use. The machine developed was tested using three different pavement types (bare soil, concrete, and asphalt).

\section{The snow blower prototype developed}

The snow blower prototype is composed in schematic mode by a frame on which it is present a screw conveyor, two blowers, and an internal combustion engine (Figure 1). The prototype has a mass of $91 \mathrm{~kg}$ and it is fixed to the vehicle by two supports hinged at the steel frame. An electrical winch is used to raise (transport position) and lower (working position) the implement. A steel blade, placed under the screw, scrapes the snow from the pavement, and the screw conveys it to the blowers. The deflectors mounted on the blowers are adjusted using an electrical cylinder (usually are inclined by $30^{\circ}$ ). Successively, the blowers expel and piling the snow on roadside. The prototype is driven by a 4-stroke internal combustion engine of $15 \mathrm{~kW}$ of nominal power fed with gasoline (Honda GX630) and shows a working width of $1.70 \mathrm{~m}$. All movements of the machine are controlled with a unit placed near the driver's seat.

\section{Materials and methods}

Trials were carried out at Halifax in Canada during 2015 and 2016 winter seasons. The snow blower was tested on three different vehicles type: car, tractor, and quad-bike. In detail, the car used was a Toyota $4 \times 4$ Pickup 5-Speed - $2400 \mathrm{CC}$ with a mass of 2449 $\mathrm{kg}$ and a width (external wheel to external wheel) of $1689 \mathrm{~mm}$. The tractor was a small tractor common used for cutting grass (model Honda H5013A4) characterised by a nominal power of $9.7 \mathrm{~kW}$ and a width (external wheel to external wheel) of $1050 \mathrm{~mm}$. The quadbike, in comparison, was a Honda Foreman TRX500 and it was powered by an internal combustion engine of $21.1 \mathrm{~kW}$ (Table 1).

The prototype performance was evaluated on three different pavement surface: bare soil, concrete, and asphalt. The test plots were collocated in a topographically flat area, each with an approximate surface area of $4000 \mathrm{~m}^{2}$ and a minimum length of 120 meters. This later technical characteristic was very important because authors believe that a length of 100 meters was acceptable for prototype performances evaluation considering its low working forward speed (lower than $3 \mathrm{~km} \mathrm{~h}^{-1}$ ) (Manzone and Balsari, 2014). For this reason, each test was performed on a plot of $220 \mathrm{~m}^{2}(110$ meters in length and 2 meters in width); five meter before and after and 0.20 meters outside the testing area $(100.0 \times 1.6 \mathrm{~m})$ were considered due to not damage the adjacent plot. Each area was levelled and not presented obstacles. Since the different snow physical characteristics (hardness, density,...) mainly linked to climate and weather conditions (Armstrong and Brun, 2008) could interfere on prototype performances, tests were performed in similar snow conditions. At this purpose, authors were considered as key physical parameters: snow density, snow hardness, and residual liquid water. In fact, the snow density could interfere on blower perfor- mance because it is easier to blow light snow (low snow density) compared to heavy snow (high snow density), while a higher snow hardness level could generate a higher resistance force to prototype forwarding. In contrast, a higher presence of residual liquid water could make easy the snow sliding between the mechanical components because the liquid water could be considered such as lubricant. Following the snow classification proposed by Frierz et al. (2009), trials were carried out considering a total snow density between $80-180 \mathrm{~kg} \mathrm{~m}^{-3}$, soft-medium level of hardness, and a presence of residual liquid water content of $0-2 \%$ (dry-most on snow classification). The density was determined weighing a cubic plastic box of $0.125 \mathrm{~m}^{-3}$ capacity $(500 \times 500 \times 500 \mathrm{~mm})$ by a digital scale (SINERGICA ${ }^{\circledR}$ SFB 60K20LHIPM) with a readability of $0.02 \mathrm{~kg}$. The snow hardness was estimated using the hand test proposed by De Quervain (1950). Since the hand test is a relative test, the operator chosen for this measurement have calibrated his hand force with ramsonde measuring instrument (Takeuchi et al., 1998). The residual liquid water content was estimate using the visual method proposed by McClung and Schaerer (1993) and considering the ICSI (International Commission on Snow and Ice) classification.

In order to individuate the real potentiality and limits of the machine developed, its performances were evaluated on different snow layer thickness $(50,100,150,200,250$, and $300 \mathrm{~mm})$.

The thickness of each snow layer was measured using a rigid ruler of $600 \mathrm{~mm}$ length and with an accuracy of $1 \mathrm{~mm}$.

\section{Forward speed and productivity}

For all different snow layer thickness, the correct working forward speed was considered with visual check: during the working operation the snow did not accumulate in front of the prototype. Forward speed value was determined with the arithmetic method considering the time required to travel a distance of 100 meters. Time recording was performed using two couples of photocells (ZOOM ${ }^{\circledR} \mathrm{Z2E}$ ) placed at the distance of 100 meters (first couple started the timer and the second couple stopped the timer). As

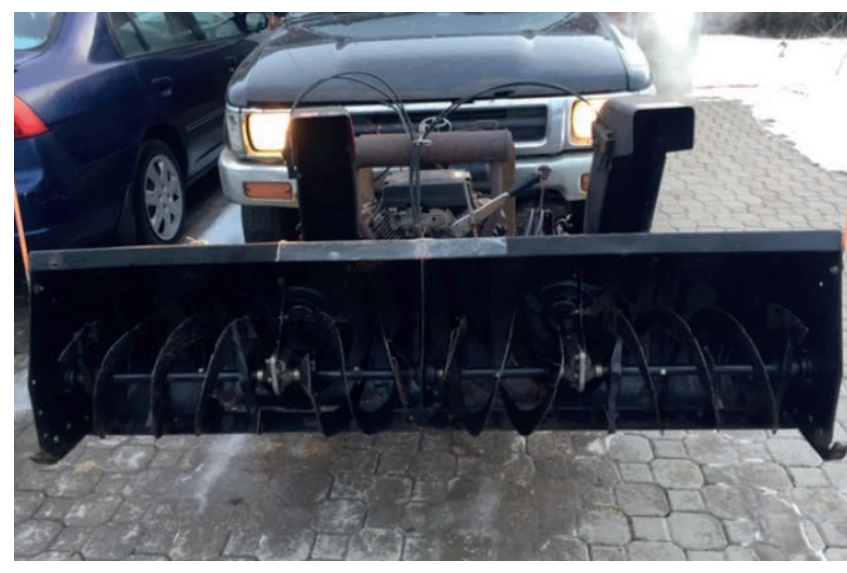

Figure 1. The snow blower prototype tested.

Table 1. Technical characteristics of vehicles used in the tests.

\begin{tabular}{llccccc} 
Vehicle type & Model & Power $(\mathrm{kW})$ & Mass $(\mathrm{kg})$ & Width $(\mathrm{mm})$ & Length $(\mathrm{mm})$ & ${\text { Wheels drive }\left(\mathrm{n}^{\circ}\right)}$ \\
Car & Toyota 2.4 & 55.9 & 2449 & 1689 & 5054 & 4 \\
Tractor & Honda H5013A4 & 9.7 & 464 & 1050 & 2180 & 4 \\
\hline Quad-bike & Honda Foreman TRX500 & 21.1 & 287 & 1204 & 2103 & 4 \\
\hline
\end{tabular}


already previously mentioned, the photocells were positioned at the distance from the beginning of the plot of 10 meters. This method was adapted in order to stabilise the forward speed of the prototype in working conditions. A flexible ruler (LUX®) with accuracy of $2 \mathrm{~mm}$ was used for the measurements. Travel time were determined with a centesimal digital stopwatch (Hanhart ${ }^{\circledR}$ PROFIL 5).

Productivity was calculated dividing the worked surface $\left(\mathrm{m}^{2}\right)$ for time spent to work it (min).

\section{Working quality}

In this study, the working quality was evaluated measuring in term of volume the amount of snow present on surface worked after the prototype passage. This measurement was performed filling graduate cubic boxes of $1 \mathrm{dm}^{3}$ capacity with the snow collected. The accuracy of these measurements was $0.05 \mathrm{dm}^{3}$.

\section{Fuel consumption}

The fuel consumption was determined by the topping-off system; the fuel amount used to refill the tank was considered that required to perform the working operation. For this reason, the vehicle tank was refilled after each test. In detail, the tank was refilled using a $1000 \mathrm{~cm}^{3}$ glass pipe with $10 \mathrm{~cm}^{3}$ graduations, corresponding to the accuracy of the measurements. Again, it was calculated also the specific fuel consumption for the snow removing operations, considering the real power required to drive the blower prototype tested.

The data were processed using Microsoft Excel and SPSS 22
(2017) statistical software. Differences between treatments were checked with the Tukey's test (adopting a significance level of $\alpha=0.05$ ) because it has a higher statistical power given this data distribution.

\section{Results}

\section{Forward speed and productivity}

The highest forward speed $\left(2.51 \mathrm{~km} \mathrm{~h}^{-1}\right)$ was obtained using the car on asphalt pavement working with a snow layer thickness of $50 \mathrm{~mm}$. In contrast, the lowest forward speed $\left(0.28 \mathrm{~km} \mathrm{~h}^{-1}\right)$ was observed when the prototype was fixed to the quad-bike and it worked on concrete soil with a height snow of $300 \mathrm{~mm}$ (Table 2). Since the productivity is linked to forward speed, the same values trend was observed also for this parameter. The lowest productivity $\left(7.5 \mathrm{~m}^{2} \mathrm{~min}^{-1}\right)$ was obtained by quad-bike on concrete with highest snow presence $(300 \mathrm{~mm})$, compared to the highest productivity $\left(66.9 \mathrm{~m}^{2} \mathrm{~min}^{-1}\right)$ resulted using car with a lowest snow presence $(50$ $\mathrm{mm}$ ) (Table 3). Results showed significantly different performances (forward speed and productivity) only between snow thickness; there were no significant differences between pavement types (asphalt, concrete, and bare soil) and vehicles types (car, tractor, and quad-bike) (Tables 2 and 3). Additionally, it is possible to consider the forward speed, and consequently also the productivity, only in function of snow thickness (Figure 2).

Table 2. Forward speed $\left(\mathrm{km} \mathrm{h}^{-1}\right)$ obtained with different snow layer thickness and vehicles type.

\begin{tabular}{|c|c|c|c|c|c|c|c|}
\hline Machines & Surface type & & & Hei & $(\mathrm{mm})$ & & \\
\hline & & 50 & 100 & 150 & 200 & 250 & 300 \\
\hline Car & Asphalt & $2.51^{\mathrm{a}, \mathrm{a}}$ & $2.16^{\mathrm{a}, \mathrm{b}}$ & $1.69^{\mathrm{a}, \mathrm{c}}$ & $1.41^{\mathrm{a}, \mathrm{d}}$ & $0.72^{\mathrm{a}, \mathrm{e}}$ & $0.31^{\mathrm{a}, \mathrm{f}}$ \\
\hline & Concrete & $2.49^{\mathrm{a}, \mathrm{a}}$ & $2.13^{a, b}$ & $1.68^{a, c}$ & $1.39^{\mathrm{a}, \mathrm{d}}$ & $0.69^{\mathrm{a}, \mathrm{e}}$ & $0.29^{\mathrm{a}, \mathrm{f}}$ \\
\hline & Bare soil & $2.45^{\mathrm{a}, \mathrm{a}}$ & $2.15^{\mathrm{a}, \mathrm{b}}$ & $1.70^{\mathrm{a}, \mathrm{c}}$ & $1.39^{\mathrm{a}, \mathrm{d}}$ & $0.71^{\mathrm{a}, \mathrm{e}}$ & $0.29^{\mathrm{a}, \mathrm{f}}$ \\
\hline Tractor & Asphalt & $2.47^{\mathrm{a}, \mathrm{a}}$ & $2.21^{\mathrm{a}, \mathrm{b}}$ & $1.68^{a, c}$ & $1.38^{\mathrm{a}, \mathrm{d}}$ & $0.70^{\mathrm{a}, \mathrm{e}}$ & $0.31^{\mathrm{a}, \mathrm{f}}$ \\
\hline & Concrete & $2.44^{\mathrm{a}, \mathrm{a}}$ & $2.16^{a, b}$ & $1.66^{\mathrm{a}, \mathrm{c}}$ & $1.40^{\mathrm{a}, \mathrm{d}}$ & $0.68^{\mathrm{a}, \mathrm{e}}$ & $0.30^{\mathrm{a}, \mathrm{f}}$ \\
\hline & Soil & $2.48^{\mathrm{a}, \mathrm{a}}$ & $2.17^{\mathrm{a}, \mathrm{b}}$ & $1.68^{\mathrm{a}, \mathrm{c}}$ & $1.39^{\mathrm{a}, \mathrm{d}}$ & $0.70^{\mathrm{a}, \mathrm{e}}$ & $0.29^{\mathrm{a}, \mathrm{f}}$ \\
\hline Quad-bike & Asphalt & $2.50^{\mathrm{a}, \mathrm{a}}$ & $2.16^{\mathrm{a}, \mathrm{b}}$ & $1.70^{\mathrm{a}, \mathrm{c}}$ & $1.37^{\mathrm{a}, \mathrm{d}}$ & $0.69^{\mathrm{a}, \mathrm{e}}$ & $0.30^{\mathrm{a}, \mathrm{f}}$ \\
\hline & Concrete & $2.49^{\mathrm{a}, \mathrm{a}}$ & $2.18^{a, b}$ & $1.67^{\mathrm{a}, \mathrm{c}}$ & $1.41^{\mathrm{a}, \mathrm{d}}$ & $0.71^{\mathrm{a}, \mathrm{e}}$ & $0.28^{\mathrm{a}, \mathrm{f}}$ \\
\hline & Soil & $2.48^{\mathrm{a}, \mathrm{a}}$ & $2.18^{a, b}$ & $1.67^{\mathrm{a}, \mathrm{c}}$ & $1.38^{\mathrm{a}, \mathrm{d}}$ & $0.68^{\mathrm{a}, \mathrm{e}}$ & $0.31^{\mathrm{a}, \mathrm{f}}$ \\
\hline Mean & - & 2.48 & $2.16^{a, b}$ & 1.68 & 1.39 & 0.70 & 0.30 \\
\hline
\end{tabular}

Values in table are a mean of 3 test replications; the first letter indicates the statistical difference between soil type and vehicles used, the second letter indicates the statistical difference obtained with different heights snow.

Table 3. Productivity $\left(\mathrm{m}^{2} \mathrm{~min}^{-1}\right)$ obtained with different snow layer thickness and vehicles type.

\begin{tabular}{|c|c|c|c|c|c|c|c|}
\hline \multirow[t]{2}{*}{ Machines } & \multirow[t]{2}{*}{ Surface type } & \multicolumn{6}{|c|}{ Height snow (mm) } \\
\hline & & 50 & 100 & 150 & 200 & 250 & 300 \\
\hline \multirow[t]{3}{*}{ Car } & Asphalt & $66.9^{\mathrm{a}, \mathrm{a}}$ & $57.6^{\mathrm{a}, \mathrm{b}}$ & $45.1^{\mathrm{a}, \mathrm{c}}$ & $37.6^{\mathrm{a}, \mathrm{d}}$ & $19.2^{\mathrm{a}, \mathrm{e}}$ & $8.0^{\mathrm{a}, \mathrm{f}}$ \\
\hline & Concrete & $66.4^{\mathrm{a}, \mathrm{a}}$ & $56.8^{\mathrm{a}, \mathrm{b}}$ & $44.8^{a, c}$ & $37.1^{\mathrm{a}, \mathrm{d}}$ & $18.4^{\mathrm{a}, \mathrm{e}}$ & $7.7^{\mathrm{a}, \mathrm{f}}$ \\
\hline & Soil & $65.3^{\mathrm{a}, \mathrm{a}}$ & $57.3^{\mathrm{a}, \mathrm{b}}$ & $45.3^{\mathrm{a}, \mathrm{c}}$ & $37.1^{\mathrm{a}, \mathrm{d}}$ & $18.9^{a, e}$ & $7.7^{\mathrm{a}, \mathrm{f}}$ \\
\hline \multirow[t]{3}{*}{ Tractor } & Asphalt & $65.9^{\mathrm{a}, \mathrm{a}}$ & $58.9^{\mathrm{a}, \mathrm{b}}$ & $44.8^{a, c}$ & $36.8^{\mathrm{a}, \mathrm{d}}$ & $18.7^{\mathrm{a}, \mathrm{e}}$ & $8.3^{\mathrm{a}, \mathrm{f}}$ \\
\hline & Concrete & $65.1^{\mathrm{a}, \mathrm{a}}$ & $57.6^{\mathrm{a}, \mathrm{b}}$ & $44.3^{\mathrm{a}, \mathrm{c}}$ & $37.3^{\mathrm{a}, \mathrm{d}}$ & $18.1^{a, e}$ & $8.0^{\mathrm{a}, \mathrm{f}}$ \\
\hline & Soil & $66.1^{\mathrm{a}, \mathrm{a}}$ & $57.9^{\mathrm{a}, \mathrm{b}}$ & $44.8^{\mathrm{a}, \mathrm{c}}$ & $37.1^{a, d}$ & $18.7^{\mathrm{a}, \mathrm{e}}$ & $7.7^{\mathrm{a}, \mathrm{f}}$ \\
\hline \multirow[t]{3}{*}{ Quad-bike } & Asphalt & $66.7^{\mathrm{a}, \mathrm{a}}$ & $57.6^{\mathrm{a}, \mathrm{b}}$ & $45.3^{\mathrm{a}, \mathrm{c}}$ & $36.5^{\mathrm{a}, \mathrm{d}}$ & $18.4^{\mathrm{a}, \mathrm{e}}$ & $8.0^{a, f}$ \\
\hline & Concrete & $66.4^{\mathrm{a}, \mathrm{a}}$ & $58.1^{\mathrm{a}, \mathrm{b}}$ & $44.5^{\mathrm{a}, \mathrm{c}}$ & $37.6^{\mathrm{a}, \mathrm{d}}$ & $18.9^{\mathrm{a}, \mathrm{e}}$ & $7.5^{\mathrm{a}, \mathrm{f}}$ \\
\hline & Soil & $66.1^{\mathrm{a}, \mathrm{a}}$ & $58.1^{a, b}$ & $44.5^{\mathrm{a}, \mathrm{c}}$ & $36.8^{\mathrm{a}, \mathrm{d}}$ & $18.1^{\mathrm{a}, \mathrm{e}}$ & $8.3^{\mathrm{a}, \mathrm{f}}$ \\
\hline Mean & - & 66.1 & 57.8 & 44.8 & 37.1 & 18.6 & 7.9 \\
\hline
\end{tabular}

Values in table is a mean of 3 test replications; the first letter indicates the statistical difference between soil type and vehicles used, the second letter indicates the statistical difference obtained with different heights snow. 


\section{Working quality}

The prototype has demonstrated good functionality leaving only a minor residual snow layer after its passage of about 0.18 $\mathrm{dm}^{3}$ on 100 meter of road (Table 4).

Statistical analysis showed no significant different performances changed the vehicles type and working in different pavement surface. In addition, statistical analysis showed also that the snow layer thickness did not affect the working quality (Table 4).

\section{Fuel consumption}

The hourly fuel consumption varied between 6.56 and 6.68 litres but, from statistic point of view, no significant differences were found between test results (Table 5 and Figure 3).

Referring to the fuel consumption for the unit of worked surface, the worst performances (average value of $0.838 \mathrm{~L} \mathrm{~m}^{-2}$ ) were obtained with greatest snow depth $(300 \mathrm{~mm})$, instead the best performances were observed with slowest snow depth (average value of $0.099 \mathrm{~L} \mathrm{~m}^{-2}$ ) independent by the vehicles type used and surface type. Data processing showed statistical difference only between different snow layer thickness (Table 6). Fuel consumption for unit cleaned surface increased according to snow layer thickness with an exponential trend that was independent of the surface type and the vehicle models (Figure 4).

Results indicate an average specific fuel consumption of 319.5 $\mathrm{g} \mathrm{kWh}^{-1}$. For this parameter, no differences between values obtained in the different tests were found (Table 7).

\section{Discussion}

Under testing conditions, the prototype have guaranteed good performances independent of pavement type and vehicle used for its forwarding. This result is very important and must not be under estimate because highlights of a high versatility of machine developed: essential feature to work in urban and private areas. In fact, on environmental urban or in private areas it is possible to find different pavement type in function of working surface (open spaces, courtyard, roads, sidewalks, ...) (Litzka, 2002; Castro et al., 2007). In addition, especially in private use, the possibility to use different vehicle types to move the prototype showing always the same performances could be a great advantage because it is possible to change the vehicle model without interference on snow removing quality or to be forced to change also the snow blower. This advan-

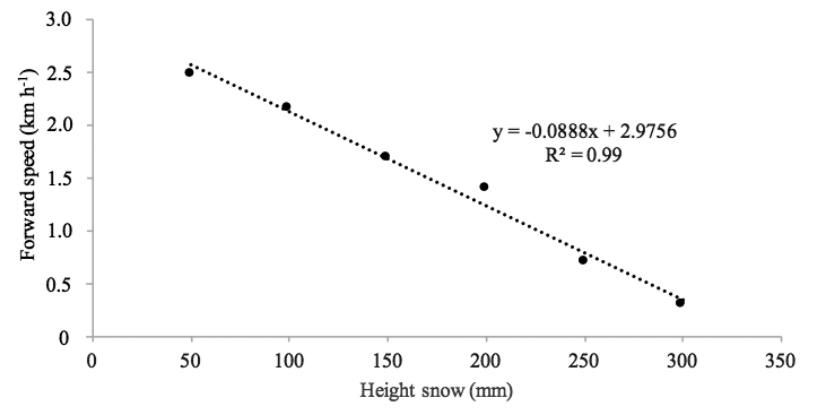

Figure 2. Forward speed on the snow blower tested as a function of the snow layer thickness.

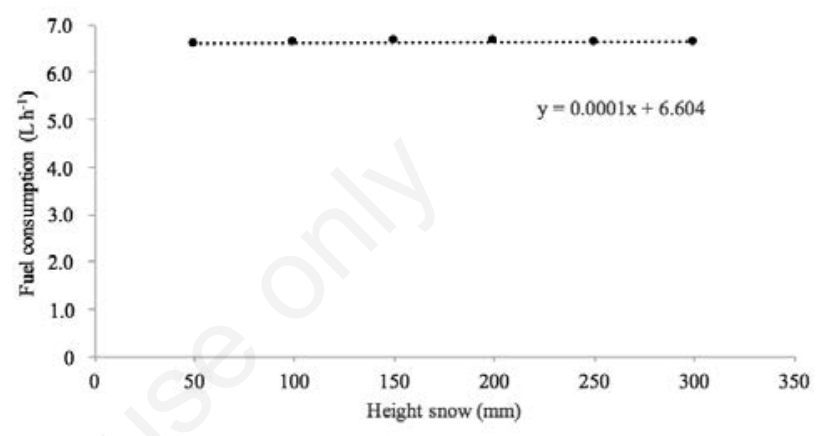

Figure 3. Hourly fuel consumption as a function of the snow layer thickness.

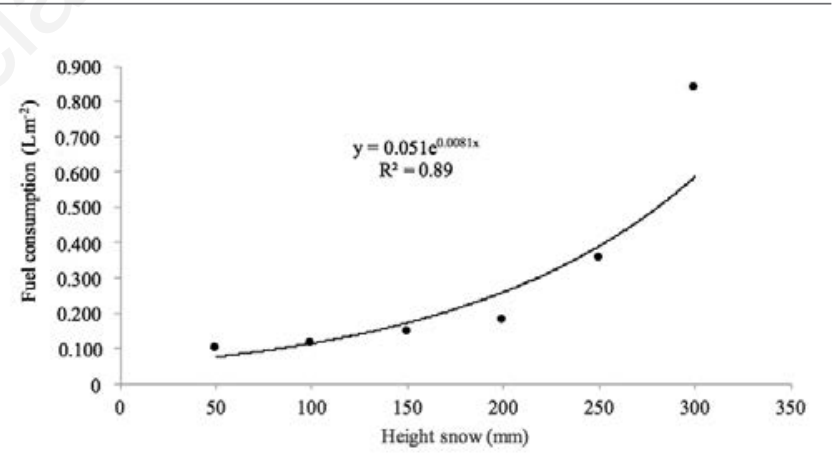

Figure 4. Fuel consumption per unit worked surface as a function of the snow layer thickness.

Table 4. Snow volume after the passage of the prototype $\left(\mathrm{dm}^{3}\right.$ on 100 meter of road).

\begin{tabular}{|c|c|c|c|c|c|c|c|}
\hline \multirow[t]{2}{*}{ Machines } & \multirow{2}{*}{ Surface type } & \multicolumn{6}{|c|}{ Height snow (mm) } \\
\hline & & 50 & 100 & 150 & 200 & 250 & 300 \\
\hline \multirow[t]{3}{*}{ Car } & Asphalt & $0.20^{\mathrm{a}, \mathrm{a}}$ & $0.18^{\mathrm{a}, \mathrm{a}}$ & $0.22^{\mathrm{a}, \mathrm{a}}$ & $0.14^{\mathrm{a}, \mathrm{a}}$ & $0.18^{\mathrm{a}, \mathrm{a}}$ & $0.18^{\mathrm{a}, \mathrm{a}}$ \\
\hline & Concrete & $0.17^{\text {a, a }}$ & $0.15^{\mathrm{a}, \mathrm{a}}$ & $0.14^{\mathrm{a}, \mathrm{a}}$ & $0.21^{\mathrm{a}, \mathrm{a}}$ & $0.21^{\mathrm{a}, \mathrm{a}}$ & $0.21^{\mathrm{a}, \mathrm{a}}$ \\
\hline & Soil & $0.16^{\mathrm{a}, \mathrm{a}}$ & $0.20^{\mathrm{a}, \mathrm{a}}$ & $0.19^{\mathrm{a}, \mathrm{a}}$ & $0.17^{\mathrm{a}, \mathrm{a}}$ & $0.19^{\mathrm{a}, \mathrm{a}}$ & $0.16^{\mathrm{a}, \mathrm{a}}$ \\
\hline \multirow[t]{3}{*}{ Tractor } & Asphalt & $0.21^{\mathrm{a}, \mathrm{a}}$ & $0.14^{\mathrm{a}, \mathrm{a}}$ & $0.16^{\mathrm{a}, \mathrm{a}}$ & $0.22^{\mathrm{a}, \mathrm{a}}$ & $0.15^{\mathrm{a}, \mathrm{a}}$ & $0.20^{\mathrm{a}, \mathrm{a}}$ \\
\hline & Concrete & $0.18^{a, a}$ & $0.17^{\mathrm{a}, \mathrm{a}}$ & $0.19^{\mathrm{a}, \mathrm{a}}$ & $0.19 \mathrm{a}, \mathrm{a}$ & $0.18^{a, a}$ & $0.22^{\mathrm{a}, \mathrm{a}}$ \\
\hline & Soil & $0.20^{\mathrm{a}, \mathrm{a}}$ & $0.19 \mathrm{a}, \mathrm{a}$ & $0.16^{\mathrm{a}, \mathrm{a}}$ & $0.19 \mathrm{a}, \mathrm{a}$ & $0.18^{a, a}$ & $0.19^{a, a}$ \\
\hline \multirow[t]{3}{*}{ Quad-bike } & Asphalt & $0.14^{\mathrm{a}, \mathrm{a}}$ & $0.15^{\mathrm{a}, \mathrm{a}}$ & $0.20^{\mathrm{a}, \mathrm{a}}$ & $0.16^{\mathrm{a}, \mathrm{a}}$ & $0.14^{\mathrm{a}, \mathrm{a}}$ & $0.19^{\mathrm{a}, \mathrm{a}}$ \\
\hline & Concrete & $0.18^{a, a}$ & $0.20^{\mathrm{a}, \mathrm{a}}$ & $0.18^{\mathrm{a}, \mathrm{a}}$ & $0.18^{\mathrm{a}, \mathrm{a}}$ & $0.20^{\mathrm{a}, \mathrm{a}}$ & $0.18^{\mathrm{a}, \mathrm{a}}$ \\
\hline & Soil & $0.21^{\mathrm{a}, \mathrm{a}}$ & $0.18^{\mathrm{a}, \mathrm{a}}$ & $0.18^{\mathrm{a}, \mathrm{a}}$ & $0.17^{\mathrm{a}, \mathrm{a}}$ & $0.18^{\mathrm{a}, \mathrm{a}}$ & $0.19^{\mathrm{a}, \mathrm{a}}$ \\
\hline Mean & - & 0.18 & 0.17 & 0.18 & 0.18 & 0.18 & 0.19 \\
\hline
\end{tabular}

Values in table is a mean of 3 test replications; the first letter indicates the statistical difference between soil type and vehicles used, the second letter indicates the statistical difference obtained with different heights snow. 
tage can be considered valid also from a commercial point of view. In fact, many private owners do not sell these machines because the market offers only specific equipment to fix in front of tractors or self-propelled machines where their expensive price and maintenance cost related to low use (personal use) does not justify the purchase.

Data processing showed also another advantage in the use of the snow blower tested that is to guarantee a good working quality with different snow layers' thickness (up to height of $300 \mathrm{~mm}$ ). That aspect is essential on a logistic planning of the snow-removal operations because it permits medium-long interval between the passages also when snowing.

Trials have highlighted a low-medium forward speed of the prototype proposed during the work, especially when the snow height is higher than $200 \mathrm{~mm}\left(0.7 \mathrm{~km} \mathrm{~h}^{-1}\right)$. This result, if in private environments is not a problem because in personal use the machineries' productivity is not assumed as a priority, could be considered a limit in urban areas where it could generate some problems of traffic congestions (Hong et al., 2015). At this regard, readers must consider that the forward speed of the snow blower is

Table 5. Hourly fuel consumptions $\left(\mathrm{L} \mathrm{h}^{-1}\right)$ observed with different snow height and vehicles.

\begin{tabular}{|c|c|c|c|c|c|c|c|}
\hline \multirow[t]{2}{*}{ Machines } & \multirow[t]{2}{*}{ Surface type } & \multicolumn{6}{|c|}{ Height snow (mm) } \\
\hline & & 50 & 100 & 150 & 200 & 250 & 300 \\
\hline \multirow[t]{3}{*}{ Car } & Asphalt & $6.62^{\mathrm{a}, \mathrm{a}}$ & $6.65^{\mathrm{a}, \mathrm{a}}$ & $6.68^{\mathrm{a}, \mathrm{a}}$ & $6.66^{\mathrm{a}, \mathrm{a}}$ & $6.68^{\mathrm{a}, \mathrm{a}}$ & $6.66^{\mathrm{a}, \mathrm{a}}$ \\
\hline & Concrete & $6.57^{\mathrm{a}, \mathrm{a}}$ & $6.54^{\mathrm{a}, \mathrm{a}}$ & $6.64^{\mathrm{a}, \mathrm{a}}$ & $6.60^{\mathrm{a}, \mathrm{a}}$ & $6.63^{\mathrm{a}, \mathrm{a}}$ & $6.64^{\mathrm{a}, \mathrm{a}}$ \\
\hline & Soil & $6.60^{\mathrm{a}, \mathrm{a}}$ & $6.59^{\mathrm{a}, \mathrm{a}}$ & $6.61^{\mathrm{a}, \mathrm{a}}$ & $6.60^{\mathrm{a}, \mathrm{a}}$ & $6.62^{\mathrm{a}, \mathrm{a}}$ & $6.63^{\mathrm{a}, \mathrm{a}}$ \\
\hline \multirow[t]{3}{*}{ Tractor } & Asphalt & $6.59^{\mathrm{a}, \mathrm{a}}$ & $6.63^{\mathrm{a}, \mathrm{a}}$ & $6.62^{\mathrm{a}, \mathrm{a}}$ & $6.62^{\mathrm{a}, \mathrm{a}}$ & $6.66^{\mathrm{a}, \mathrm{a}}$ & $6.62^{\mathrm{a}, \mathrm{a}}$ \\
\hline & Concrete & $6.67^{\mathrm{a}, \mathrm{a}}$ & $6.68^{\mathrm{a}, \mathrm{a}}$ & $6.65^{\mathrm{a}, \mathrm{a}}$ & $6.67^{\mathrm{a}, \mathrm{a}}$ & $6.61^{\mathrm{a}, \mathrm{a}}$ & $6.59^{\mathrm{a}, \mathrm{a}}$ \\
\hline & Soil & $6.59^{\mathrm{a}, \mathrm{a}}$ & $6.55^{\mathrm{a}, \mathrm{a}}$ & $6.63^{\mathrm{a}, \mathrm{a}}$ & $6.66^{\mathrm{a}, \mathrm{a}}$ & $6.64^{\mathrm{a}, \mathrm{a}}$ & $6.64^{\mathrm{a}, \mathrm{a}}$ \\
\hline \multirow[t]{3}{*}{ Quad-bike } & Asphalt & $6.56^{\mathrm{a}, \mathrm{a}}$ & $6.68^{\mathrm{a}, \mathrm{a}}$ & $6.65^{\mathrm{a}, \mathrm{a}}$ & $6.64^{\mathrm{a}, \mathrm{a}}$ & $6.58^{\mathrm{a}, \mathrm{a}}$ & $6.62^{\mathrm{a}, \mathrm{a}}$ \\
\hline & Concrete & $6.57^{\mathrm{a}, \mathrm{a}}$ & $6.61^{\mathrm{a}, \mathrm{a}}$ & $6.62^{\mathrm{a}, \mathrm{a}}$ & $6.68^{a, a}$ & $6.61^{\mathrm{a}, \mathrm{a}}$ & $6.67^{\mathrm{a}, \mathrm{a}}$ \\
\hline & Soil & $6.61^{\mathrm{a}, \mathrm{a}}$ & $6.56^{\mathrm{a}, \mathrm{a}}$ & $6.66^{\mathrm{a}, \mathrm{a}}$ & $6.60^{\mathrm{a}, \mathrm{a}}$ & $6.65^{\mathrm{a}, \mathrm{a}}$ & $6.58^{\mathrm{a}, \mathrm{a}}$ \\
\hline Mean & - & 6.60 & 6.61 & 6.64 & 6.64 & 6.63 & 6.63 \\
\hline
\end{tabular}

Values in table is a mean of 3 test replications; the first letter indicates the statistical difference between soil type and vehicles used, the second letter indicates the statistical difference obtained with different heights snow.

Table 6. Fuel consumptions for unit worked surface $\left(\mathrm{L} \mathrm{m}^{-2}\right)$.

\begin{tabular}{|c|c|c|c|c|c|c|c|}
\hline Machines & Surface type & & & Heig & $(\mathrm{mm})$ & & \\
\hline & & 50 & 100 & 150 & 200 & 250 & 300 \\
\hline Car & Asphalt & $0.098^{\mathrm{a}, \mathrm{a}}$ & $0.115^{\mathrm{a}, \mathrm{b}}$ & $0.148^{a, c}$ & $0.175^{\mathrm{a}, \mathrm{d}}$ & $0.347^{\mathrm{a}, \mathrm{e}}$ & $0.832^{\mathrm{a}, \mathrm{f}}$ \\
\hline & Concrete & $0.098^{\mathrm{a}, \mathrm{a}}$ & $0.115^{\mathrm{a}, \mathrm{b}}$ & $0.148^{a, c}$ & $0.178^{\mathrm{a}, \mathrm{d}}$ & $0.360^{\mathrm{a}, \mathrm{e}}$ & $0.858^{\mathrm{a}, \mathrm{f}}$ \\
\hline & Soil & $0.101^{\mathrm{a}, \mathrm{a}}$ & $0.114^{\mathrm{a}, \mathrm{b}}$ & $0.145^{\mathrm{a}, \mathrm{c}}$ & $0.178^{\mathrm{a}, \mathrm{d}}$ & $0.349^{\mathrm{a}, \mathrm{e}}$ & $0.857^{\mathrm{a}, \mathrm{f}}$ \\
\hline Tractor & Asphalt & $0.100^{\mathrm{a}, \mathrm{a}}$ & $0.112^{a, b}$ & $0.147^{\mathrm{a}, \mathrm{c}}$ & $0.179^{\mathrm{a}, \mathrm{d}}$ & $0.356^{\mathrm{a}, \mathrm{e}}$ & $0.800^{a}, \mathrm{f}$ \\
\hline & Concrete & $0.102^{\mathrm{a}, \mathrm{a}}$ & $0.116^{\mathrm{a}, \mathrm{b}}$ & $0.150^{\mathrm{a}, \mathrm{c}}$ & $0.178^{\mathrm{a}, \mathrm{d}}$ & $0.364^{\mathrm{a}, \mathrm{e}}$ & $0.823^{a, f}$ \\
\hline & Soil & $0.099^{\mathrm{a}, \mathrm{a}}$ & $0.113^{a, b}$ & $0.148^{\mathrm{a}, \mathrm{c}}$ & $0.179^{\mathrm{a}, \mathrm{d}}$ & $0.355^{\mathrm{a}, \mathrm{e}}$ & $0.858^{\mathrm{a}, \mathrm{f}}$ \\
\hline Quad-bike & Asphalt & $0.098^{\mathrm{a}, \mathrm{a}}$ & $0.116^{\mathrm{a}, \mathrm{b}}$ & $0.146^{\mathrm{a}, \mathrm{c}}$ & $0.181^{\mathrm{a}, \mathrm{d}}$ & $0.357^{\mathrm{a}, \mathrm{e}}$ & $0.827^{\mathrm{a}, \mathrm{f}}$ \\
\hline & Concrete & $0.098^{\mathrm{a}, \mathrm{a}}$ & $0.113^{a, b}$ & $0.148^{a, c}$ & $0.177^{\mathrm{a}, \mathrm{d}}$ & $0.349^{\mathrm{a}, \mathrm{e}}$ & $0.893^{\mathrm{a}, \mathrm{f}}$ \\
\hline & & $0.099^{\mathrm{a}, \mathrm{a}}$ & $0.112^{\mathrm{a}, \mathrm{b}}$ & $0.149^{\mathrm{a}, \mathrm{c}}$ & $0.179^{\mathrm{a}, \mathrm{d}}$ & $0.366^{\mathrm{a}, \mathrm{e}}$ & $0.795^{\mathrm{a}, \mathrm{f}}$ \\
\hline Mean & - & 0.099 & 0.114 & 0.148 & 0.178 & 0.356 & 0.838 \\
\hline
\end{tabular}

Values in table is a mean of 3 test replications; the first letter indicates the statistical difference between soil type and vehicles used, the second letter indicates the statistical difference obtained with different heights snow.

Table 7. Specific fuel consumptions $\left(\mathrm{g} \mathrm{kWh}^{-1}\right)$.

\begin{tabular}{|c|c|c|c|c|c|c|c|}
\hline \multirow{2}{*}{ Machines } & \multirow[t]{2}{*}{ Surface type } & \multicolumn{6}{|c|}{ Height snow (mm) } \\
\hline & & 50 & 100 & 150 & 200 & 250 & 300 \\
\hline \multirow[t]{3}{*}{ Car } & Asphalt & $319.2^{\mathrm{a}, \mathrm{a}}$ & $320.7^{\mathrm{a}, \mathrm{a}}$ & $322.1^{\mathrm{a}, \mathrm{a}}$ & $318.2^{\mathrm{a}, \mathrm{a}}$ & $322.1^{\mathrm{a}, \mathrm{a}}$ & $321.1^{\mathrm{a}, \mathrm{a}}$ \\
\hline & Concrete & $316.8^{\mathrm{a}, \mathrm{a}}$ & $315.4^{\mathrm{a}, \mathrm{a}}$ & $320.2^{\mathrm{a}, \mathrm{a}}$ & $318.3^{\mathrm{a}, \mathrm{a}}$ & $319.7^{\mathrm{a}, \mathrm{a}}$ & $320.2^{\mathrm{a}, \mathrm{a}}$ \\
\hline & Soil & $318.2^{\mathrm{a}, \mathrm{a}}$ & $317.8^{\mathrm{a}, \mathrm{a}}$ & $318.7^{\mathrm{a}, \mathrm{a}}$ & $318.3^{\mathrm{a}, \mathrm{a}}$ & $319.2^{\mathrm{a}, \mathrm{a}}$ & $319.7^{\mathrm{a}, \mathrm{a}}$ \\
\hline \multirow[t]{3}{*}{ Tractor } & Asphalt & $317.8^{\mathrm{a}, \mathrm{a}}$ & $319.7^{\mathrm{a}, \mathrm{a}}$ & $319.2^{\mathrm{a}, \mathrm{a}}$ & $319.2^{\mathrm{a}, \mathrm{a}}$ & $321.1^{\mathrm{a}, \mathrm{a}}$ & $319.2^{\mathrm{a}, \mathrm{a}}$ \\
\hline & Concrete & $321.6^{\mathrm{a}, \mathrm{a}}$ & $322.1^{\mathrm{a}, \mathrm{a}}$ & $320.7^{\mathrm{a}, \mathrm{a}}$ & $321.6^{\mathrm{a}, \mathrm{a}}$ & $318.7^{\mathrm{a}, \mathrm{a}}$ & $317.8^{\mathrm{a}, \mathrm{a}}$ \\
\hline & Soil & $317.8^{\mathrm{a}, \mathrm{a}}$ & $315.8^{\mathrm{a}, \mathrm{a}}$ & $319.7^{\mathrm{a}, \mathrm{a}}$ & $321.1^{\mathrm{a}, \mathrm{a}}$ & $320.2^{\mathrm{a}, \mathrm{a}}$ & $320.2^{\mathrm{a}, \mathrm{a}}$ \\
\hline \multirow[t]{3}{*}{ Quad-bike } & Asphalt & $316.3^{\mathrm{a}, \mathrm{a}}$ & $322.1^{\mathrm{a}, \mathrm{a}}$ & $320.7^{\mathrm{a}, \mathrm{a}}$ & $320.2^{\mathrm{a}, \mathrm{a}}$ & $317.3^{\mathrm{a}, \mathrm{a}}$ & $319.2^{\mathrm{a}, \mathrm{a}}$ \\
\hline & Concrete & $316.8^{\mathrm{a}, \mathrm{a}}$ & $318.7^{\mathrm{a}, \mathrm{a}}$ & $319.2^{\mathrm{a}, \mathrm{a}}$ & $322.1^{\mathrm{a}, \mathrm{a}}$ & $318.7^{\mathrm{a}, \mathrm{a}}$ & $321.6^{\mathrm{a}, \mathrm{a}}$ \\
\hline & Soil & $318.7^{\mathrm{a}, \mathrm{a}}$ & $316.3^{\mathrm{a}, \mathrm{a}}$ & $321.1^{\mathrm{a}, \mathrm{a}}$ & $318.2^{\mathrm{a}, \mathrm{a}}$ & $320.7^{\mathrm{a}, \mathrm{a}}$ & $317.3^{a, a}$ \\
\hline Mean & - & 318.1 & 318.7 & 320.2 & 319.7 & 319.8 & 319.6 \\
\hline
\end{tabular}

Values in table is a mean of 3 test replications; the first letter indicates the statistical difference between soil type and vehicles used, the second letter indicates the statistical difference obtained with different heights snow. 
linked to fan flow rate and, for this reason, it is possible to increase it changing the actual internal combustion engine with another of higher power. The choice of use an engine of only $15 \mathrm{~kW}$ of power to drive the prototype was performed in order to reduce the hourly fuel consumption, the mass on the equipment and the economic cost that are essential parameters to consider for a private use.

Good performances were observed also on hourly fuel consumption where the values are similar $\left(6.62 \mathrm{~L} \mathrm{~h}^{-1}\right)$ in all working conditions also with different snow eights. This parameter showed a very low variability (no statistical significant differences were found between values) because the engine worked always in correspondence of the maximum power (maximum gas); in this configuration, a variation of the resistant force linked to the different amount of snow removed does not affect the efficiency of the engine and, consequently, also the hourly fuel consumption. In support of the foregoing, there is also the analysis of the specific fuel consumptions calculated in function of the real power used. In fact, also in this case, the values were similar in all testing conditions. This trend is confirmed also on agricultural (Manzone, 2016), forestry (Manzone, 2015) and industrial (Manzone and Balsari, 2015) sectors.

Differently, if the fuel consumption was expressed in terms of unit worked surface, significant difference coming out comparing the values obtained working in different snow heights: higher is the snow layer thickness, higher is the fuel consumption. The reason of this is the different forward speed recorded by the blower tested during the snow-removal that have generated in turn a different productivity. Also this trend is well known on agricultural (Manzone, 2016) and forestry (Manzone, 2015) sectors.

On the base of good performances showed in the experimentation and the potential solutions indicate for its working limits (lower forward speed), it is possible to suggest also the use of the snow blower tested in urban areas where the use of big machines can increase the traffic congestion and accident frequency (Usman et al., 2010).

\section{Conclusions}

The snow blower tested, showing good performances in all working conditions, seems to be a valid solution in snow-removal especially in private areas where the equipment versatility plays a fundamental rule. In fact, in this contest, the possibility to work on different pavement types and the possibility to fix the equipment on different vehicles type permits to answer almost any of a customer's needs. Nevertheless, increasing the power of the engine that was proposed changes its use of urban areas where the use of big machinery could be difficult and dangerous. Based on results of this experimentation, it is possible to affirm that in the use of snow blower proposed, the only care to keep in consideration is the longitudinal stability of the vehicles used to move it.

\section{References}

Armstrong R.L., Brun E. 2008. Snow and climate: physical processes, surface energy exchange and modeling. Cambridge University Press, Cambridge, UK.

Castro D., González-Angullo N., Rodríguez J., Calzada M. 2007. The influence of paving-block shape on the infiltration capacity of permeable paving. Land Contam. Reclam. 15:335-44.
Defina A., Favenza A., Falco G., Orgiazzi D., Pini M. 2015. ASSIST: an advenced snow plough and salt spreader based on innovative Space based Technologies. 28th International Technical Meeting of the Satellite Division on the istitute of Navigtion, ION GNSS 3:2041-54.

De Quervain M. 1950. Die Festigkeitseigenschaften der Schneedecke und ihre Messung. Geofis. Pura Appl. 18:179-91.

Doudkin M.V., Pichugin S.Y., Fadeyev S.N. 2013. The analysis of road machine working elements parameters. World Appl. Sci. J. 23:151-8.

Hajibabai L., Ouyang Y. 2016. Dynamic snow plow let management under uncertain demand and service disruption. IEEE Trans. Intel. Transport. Syst. 17:2574-82.

Hong S., Hagiwara T., Takeuchi S., Lu B. 2015. Effects of weather conditions and snow removal operations on travel speed in an urban area. J. Transport. Res. Record 2842:90-101.

Laurinavičius A., Čygas D., Vaitkus A., Ratkevičius T., Bulevičius M., Mučinis D., Baltrušaitis A. 2016. Research of snow melting materials performance efficiency for road winter maintenance. Transport 31:322-32.

Litzka J. 2002. Austrian experiences with winter maintenance on porous asphalt. in Proceedings Ninth International Conference on Asphalt Pavements, Copenhagen, Denmark.

Manzone M. 2015. Energy consumption and CO2 analysis of different types of chippers used in wood biomass plantations. Appl. Ener. 156:686-92.

Manzone M. 2016. Energy consumption and CO2 emissions associated to mechanical planters used in biomass plantations. Biomass Bioener. 87:156-61.

Manzone M., Balsari P. 2014. Planters performance during a very short rotation coppice planting. Biomass Bioener. 67:188-92.

Manzone M., Balsari P. 2015. The energy consumption and economic costs of different vehicles used in transporting woodchips. Fuel 139:511-5.

McClung D., Schaerer P. 1993. The avalanche handbook. The mountaineers, Seattle, Washington, USA, 272 pp.

Ninon W.A., Gawronski T.J., Whelan A.E. 1996. Development of a model for the ice scraping process. Dept. of Transportation, Project HR361, Iowa, USA.

Nixon W.A., Qiu L. 2008. Effects of adverse weather on traffic crashes: systematic review and meta-analysis. TRB 87th Annual Meeting 2008. Paper No. 08-2320.

Perrier N., Langevin A., Campbell, J.F. 2007. A survey of models and algorithms for winter road maintenance. Part IV: Vehicle routing and fleet sizing for plowing and snow disposal. Comput. Oper. Res. 34:258-94.

Salazar-Aguilar M.A., Langevin A., Laporte G. 2012. Synchronized arc routing for snow plowing operations. Comput. Oper. Res. 39:1432-40.

Sarsembayeva A., Collins P.E.F. 2017. Evaluation of frost heave and moisture/chemical migration mechanisms in highway subsoil using a laboratory simulation method. Cold Reg. Sci. Technol. 133:26-35.

Takeuchi Y., Nohguchi Y., Kawashima K., Izumi K. 1998. Measurement of snow-hardness distribution. Ann. Glaciol. 26:27-30.

Usman T., Fu L., Miranda-Moreno, L.F. 2010. Quantifying safety benefit of winter road maintenance: accident frequency modelling. Accident Anal. Prevent. 42;1878-87.

Wooseung J., Noble J.S., Hutsel T. 2010. An integrated model to solve the winter asset and road maintenance problem. J. IIE Trans. 42:675-89. 